medRxiv preprint doi: https://doi.org/10.1101/2021.12.12.21267681; this version posted December 14, 2021. The copyright holder for this preprint (which was not certified by peer review) is the author/funder, who has granted medRxiv a license to display the preprint in perpetuity.

It is made available under a CC-BY-NC-ND 4.0 International license.

\title{
COVID-19 in French Nursing Homes during the Second Pandemic Wave: A Mixed-Methods Cross-Sectional Study
}

Morgane Dujmovic (0000-0002-0642-6606) $)^{1, \#}$, Thomas Roederer $(0000-0003-1733-8721)^{2, \#}$, Séverine Frison (0000-0002-1586-9564) ${ }^{3}$, Carla Melki ${ }^{5}$, Thomas Lauvin ${ }^{6}$, Emmanuel Grellety (0000-0001-9736-414X) ${ }^{4}$

1 -Epicentre, Paris, France, morgana.dujmovic@gmail.com

2 -Epicentre, Paris, France, thomas.roederer@epicentre.msf.org

3 -Epicentre, Paris, France, severine.frison@gmail.com

4 -Epicentre, Paris, France, emmanuel.grellety@epicentre.msf.org

5 -Médecins Sans Frontières, Paris, France, carla.melki@paris.msf.org

6-Médecins Sans Frontières, Paris, France, thomas.lauvin@paris.msf.org

\# - Authors (MD and TR) contributed equally

Correspondence: Thomas Roederer

thomas.roederer@epicentre.msf.org

Epicentre - 14-34 avenue Jean Jaurès 75019 PARIS

$\begin{array}{ll}\text { Abstract : } & 288 / 300 \\ \text { Text : } & 4110 / 4500\end{array}$ 
medRxiv preprint doi: https://doi.org/10.1101/2021.12.12.21267681; this version posted December 14, 2021. The copyright holder for this preprint (which was not certified by peer review) is the author/funder, who has granted medRxiv a license to display the preprint in perpetuity.

It is made available under a CC-BY-NC-ND 4.0 International license .

\section{$1 \quad$ ABSTRACT}

2 Introduction

3 French nursing homes were deeply affected by the first wave of the COVID-19 pandemic, with $38 \%$ of all 4 residents infected and $5 \%$ dying. Yet, little was done to prepare these facilities for the second pandemic wave, 5 and subsequent outbreak response strategies largely duplicated what had been done in the spring of 2020,

6 regardless of the unique needs of the care home environment.

7 Methods

8 A cross-sectional, mixed-methods study using retrospective, quantitative data from residents of 14 nursing 9 homes between November 2020 and mid-January 2021. Four facilities were purposively selected as qualitative 10 study sites for additional in-person, in-depth interviews in January and February 2021.

11 Results

12 The average attack rate in the 14 participating nursing facilities was $39 \%$ among staff and $61 \%$ among residents. 13 One-fifth (20) of infected residents ultimately died from COVID-19 and its complications. Failure-to-Thrive14 Syndrome (FTTS) was diagnosed in 23\% of COVID-positive residents. Those at highest risk of death were men 15 (HR=1.78; IC95: 1.18 - 2.70; $\mathrm{p}=0.006)$ with FTTS (HR=4.04; IC95: $1.93-8.48 ; \mathrm{p}<0.001)$ in facilities with delayed 16 implementation of universal FFP2 masking policies ( $H R=1.05 ;$ IC95: $1.02-1.07 ; p<0.001)$. The lowest mortality 17 was found in residents of facilities with a partial (HR=0.30; IC95: $0.18-0.51 ; p<0.001)$ or full-time physician on 18 staff ( $H R=0.20 ;$ IC95: $0.08-0.53 ; p=0.001)$. Significant themes emerging from qualitative analysis centered on 19 (i) the structural, chronic neglect of nursing homes, (ii) the negative effects of the top-down, bureaucratic 20 nature of COVID-19 crisis response, and (iii) the counterproductive effects of lockdowns on both residents and 21 staff.

\section{Conclusion}

23 Despite high resident mortality during the first pandemic wave, French nursing homes were ill-prepared for the 24 second, with risk factors (especially staffing, lack of medical support, isolation/quarantine policy etc) that affected case fatality and residents' and caregivers' overall well-being and mental health. 
medRxiv preprint doi: https://doi.org/10.1101/2021.12.12.21267681; this version posted December 14, 2021. The copyright holder for this preprint (which was not certified by peer review) is the author/funder, who has granted medRxiv a license to display the preprint in perpetuity.

It is made available under a CC-BY-NC-ND 4.0 International license .

\section{SUMMARY BOX}

What is already known?

- Though much was learned about COVID-19 in nursing homes during the first pandemic wave (Spring 2020), descriptions of the second wave in these facilities is nearly absent from the scientific literature.

- Prior COVID-19 research in nursing homes has rarely been qualitative and has almost never interviewed care home residents themselves.

- $\quad$ First-wave research indicated that much stronger outbreak and infection prevention was urgently needed to bolster nursing facilities' preparedness. Higher staff-to-resident ratios, less staff turnover, more masks, better organization, more medical support, and more epidemiological tools were found to reduce COVID$19^{\prime}$ s impact.

\section{What are the new findings?}

- Our results document a lack of preparedness for the second wave, with attack rates among staff (39\% overall) and residents (61\% overall) similar to levels seen during the first wave peak.

- Despite authorities' claims to have reinforced these structures' readiness, and despite much research into the needs in these environments, preventive measures (like strict lockdowns) remained largely unchanged and had a direct impact on residents, with $23 \%$ of COVID-positives also diagnosed with Failure-to-Thrive Syndrome.

- Qualitative results detailed how ill-suited and inflexible some preventive measures were for residents and staff alike. Participants described precarious and understaffed living and working conditions as substantial and long-standing difficulties that became critical risks during the COVID-19 outbreak, and compromised the response.

What do the new findings imply?

- These results suggest that knowledge gained during the first pandemic wave was not consistently applied to care home policy or practice in France, and that these nursing homes were not always safe environments that considered residents' mental health and well-being alongside infection prevention.

- Despite the high mortality of the first pandemic wave, French nursing homes were ill-prepared for the second. As a $5^{\text {th }}$ wave descends on France (albeit with much higher COVID-19 vaccination rates), applying the lessons from previous periods (especially with regard to staffing, isolation of the elderly, medical supplies, standard of care procedures) must be prioritized. 
medRxiv preprint doi: https://doi.org/10.1101/2021.12.12.21267681; this version posted December 14, 2021. The copyright holder for this preprint (which was not certified by peer review) is the author/funder, who has granted medRxiv a license to display the preprint in perpetuity.

It is made available under a CC-BY-NC-ND 4.0 International license .

57

58

60

61

62

63

64

\section{INTRODUCTION}

In France, state-funded nursing and care homes are the most common living arrangement for both independent seniors and those who need daily care and support. These institutions were deeply affected by the first wave of the COVID-19 pandemic, with an estimated $38 \%$ of all residents $(247,000$ cases $)$ infected with SARS-CoV-2 and $5 \%(30,395)$ succumbing to the disease from March-July 2020 . The workforce that staffs these facilities was also seriously affected, with an estimated $22 \%$ of all workers (90,000 cases) testing COVID-19 positive from late February to late May $2020[1,2]$.

In October of 2020, when rising caseloads suggested a second pandemic wave, nursing homes again braced for the worst, since no vaccine was yet approved in France (this occurred in December 2020) and some variants had begun circulating. In November of that year, the non-governmental organization (NGO) Médecins Sans Frontières (MSF) began partnering with select nursing homes in Provence and Occitania provinces, in southern France, to bolster their COVID-19 prevention and care procedures in the midst of rapidly growing medical needs, strained facilities, and understaffing (often aggravated by absenteeism spurred by workplace-acquired infections). As nursing homes transformed into places providing hospital-level care, staff were required to perform more advanced technical procedures and increased disease surveillance at a moment when human resources were depleted due to illness and overwork. Concurrently, health authorities recommended strong lockdown measures for elderly care home residents, including bans on going outside, prohibiting family visits, and confining residents to their rooms.

Despite the devastating mortality rates seen in care homes around the world throughout the pandemic, scientific literature has not yet described the second wave of COVID-19 in this environment. Published research is mostly focused on the first pandemic wave period, almost exclusively quantitative studies or systematic reviews on specific topics. Several articles report best practices for infection prevention and control (IPC) (i.e. frequent testing for staff, residents, and visitors, staff cohorting, and strict isolation policies), or recommended better evaluation of the consequences of lockdown restrictions $[3-13,14,15]$. Other lessons from the initial crisis period were that more staff $[6,8]$, support $[8,9]$, protective equipment, and overall preparation $[8-10]$ could prevent or reduce outbreaks. Lately, articles focused only on impact of vaccination on transmission among staff and residents $[16,17]$. The little qualitative research conducted during the first wave was almost 
medRxiv preprint doi: https://doi.org/10.1101/2021.12.12.21267681; this version posted December 14, 2021. The copyright holder for this preprint (which was not certified by peer review) is the author/funder, who has granted medRxiv a license to display the preprint in perpetuity.

It is made available under a CC-BY-NC-ND 4.0 International license .

84 never able to conduct in-person interviews [12, 18-24], but found that lockdowns had a significant and deleterious impact on residents, staff well-being, and staff turnover [20,21].

Our research attempts to understand the risk factors that influenced the second pandemic wave, the impact of that wave, and how staff and residents experienced this period of the pandemic in a nursing home setting.

\section{METHODS}

In this mixed-methods, cross-sectional study, we analyze retrospective COVID-19 data from 14 nursing homes being reinforced by support from MSF in order to assess the impact of the second pandemic wave as well as the effects of prevention measures on resident mortality and comorbidity. These results are given depth and detail through qualitative investigation into staff and resident experiences.

\section{Definitions}

94 Autonomy Evaluation Score (AES) measures a care home resident's level of autonomy. An AES of 1 reflects the lowest level of autonomy (i.e. confinement to a bed or armchair, serious mental function impairment, continuous caregiving required), while an AES of 6 refers to people who have fully retained their autonomy in their daily lives. The Average Weighted Autonomy Score (AWAS) is the overall AES score for a facility. This score is a proxy for the financial and human resources that a nursing home needs and has access to: the higher the AWAS, the more resources needed (staff-to-residents ratio, equipment, etc.) and the more dependent the residents. Failure to Thrive Syndrome (FTTS) is specific to elderly individuals and characterized by a rapid

101 deterioration after a physical or psychological event (Appendix 1).

\section{Study Design and Population}

103 This cross-sectional, mixed-methods study used retrospective, quantitative data from residents living in 14 104 nursing homes between November 2020 to mid-January 2021. Four nursing facilities were purposively selected

105 as qualitative study sites for additional in-person, in-depth interviews conducted between January and 106 February 2021. Qualitative study sites were selected based on whether they had passed their epidemic peak, 107 had high attack and fatality rates, were public or private facilities, and their geographic location. 
medRxiv preprint doi: https://doi.org/10.1101/2021.12.12.21267681; this version posted December 14, 2021. The copyright holder for this preprint (which was not certified by peer review) is the author/funder, who has granted medRxiv a license to display the preprint in perpetuity.

It is made available under a CC-BY-NC-ND 4.0 International license .

108

109

110

112

113

114

115

116

117

118

119

121

122

123

125

126

127

130

131

132

133

134

\section{Data Collection}

Facilities' administrative data (number of beds and staff, staff-to-resident ratios, etc), COVID-related data (confirmed cases among residents and staff, episode duration, deaths, etc) and individual, anonymized patient data (demographics, comorbidities, etc) were used for quantitative analysis.

Qualitative data was gathered using semi-structured, in-depth interviews (IDIs) during one-week ethnographic immersions in each of the four qualitative study sites. The lead investigator targeted four groups of actors, including facility administrators (directors, coordinating physicians, and nurses), clinical and facilities staff (nurses, caregivers, educators, physical therapists, maintenance crews), the residents themselves, and the residents' visiting family members. Participants were purposively selected to obtain a maximally heterogenous sample of interview participants and reflect the spectrum of opinions and experiences of everyday life nursing homes. Across the 4 qualitative study sites, a total of 47 IDIs were conducted with facility directors (4), staff members (36), and residents (7). Among the 36 staff members, 29 were caregivers and 7 provided other support functions (human resources, maintenance, cleaning, cooking). All interviewed residents were women, as were the majority of study participants overall (82.9\%). Interview length varied from 12-171 minutes (54minute average) (Appendix 4).

Telephone and face-to-face interviews were also conducted with 10 residents' family members, though family interviews are not included here in order to focus on experiences from within the nursing homes during lockdown. Nine residents refused to participate (due to fatigue, discomfort with interviewing, or COVID-19 related reasons). Caregiver participation was constrained by understaffing, overwork, fatigue, or disease, which left them with very little time or energy for interviewing.

Vulnerable residents were pre-selected under the advisement of the coordinating nurse on the permanent caregiver teams. Participants had to be able to give informed consent, capably interact, and have no major cognitive disorders. Level of autonomy (AES) did not constitute an a priori criteria for participant selection. Whenever a legal guardian or curator was designated, the latter was contacted prior to the interview to verify that consent could be obtained from the interviewee.

Question guides focused on three primary topics: the outbreak chronology, adaptation to the crisis, and the individual experience of the second pandemic wave (Appendix 3). Individual guides were adapted for those 
medRxiv preprint doi: https://doi.org/10.1101/2021.12.12.21267681; this version posted December 14 , 2021. The copyright holder for this preprint (which was not certified by peer review) is the author/funder, who has granted medRxiv a license to display the preprint in perpetuity.

It is made available under a CC-BY-NC-ND 4.0 International license .

135 living in the nursing home (residents) or working there (facility administrators and staff). All interviews were

136 voice recorded and direct observations were written in the investigator's field book. All written data were

137 anonymized upon collection. Participants' personal data was assigned a study number that was set on a

138 correspondence table kept separately from other data. Written informed consent was obtained prior to each

139 interview.

140 Preventive measures were implemented with all participants to decrease COVID-19 disease transmission risk:

141 systematic FFP2 face mask use, social distancing, hand and space disinfection, and weekly Rt-PCR tests for the

142 two field investigators.

\section{Statistical Analysis}

144 Patient data were explored using univariate analysis to highlight possible mortality risks. Univariate unadjusted

145 Cox Hazard Ratios, Kaplan-Meier estimations, and Log-Rank tests were used for multivariate analysis. A

146 stepwise procedure was followed, retaining factors with a log-rank test value <0.3. COVID-19 mortality was

147 estimated using a multilevel mixed-effects Cox model using selected factors identified in the univariate analysis.

148 Random effects on individual variables were considered and nested at the facility level [25]. Interactions

149 between potentially correlated factors (comorbidities, failure-to-thrive syndrome, autonomy level, time-related

150 variables) were accounted for while robust standard errors were computed (Appendix 7). 95\% confidence

151 intervals are presented and a significance threshold of $5 \%$ was chosen for $p$-values. Statistical analyses were

152 conducted with Stata $15^{\circledR}$ and R Studio $1.4^{\circledR}$

\section{Qualitative Analysis}

154 Data analysis was performed from January to March 2021, similar to the fieldwork period (January-February)

155 and reporting phase (March-April). Qualitative analysis combined grounded theory and hypothetico-deductive

156 analysis. Preliminary observation in five nursing homes and MSF-team reports were used to create an initial

157 checklist for systematic direct observation. In January and February 2021, 36 semi-structured IDIs were

158 conducted in three nursing homes, in combination with "external participatory observation" [26]. Questions

159 were adjusted in an iterative manner after preliminary analysis was conducted on these initial interviews. Data

160 saturation was sought throughout the interview process and discussed within the research team on a weekly

161 basis. In February 2021, 11 semi-structured IDIs were conducted in a fourth nursing home in order to assess

162 data saturation. 
medRxiv preprint doi: https://doi.org/10.1101/2021.12.12.21267681; this version posted December 14 , 2021. The copyright holder for this preprint (which was not certified by peer review) is the author/funder, who has granted medRxiv a license to display the preprint in perpetuity.

It is made available under a CC-BY-NC-ND 4.0 International license .

163

164

166

167

168

169

170

171

172

173

174

175

176

177

178

179

180

181

182

183

184

185

186

187

188

189

Interview data were processed gradually through professional transcription and verified with the interviewees when necessary. De-identification occurred during transcription (names, places, dates, distinctive personal data etc). Interview data were written, analyzed and coded in Excel spreadsheets. A first codebook with 39 data codes emerged from interview transcripts. Five themes were initially analyzed and refined into a final set of 33 across four key categories. Three of these were cross-cutting and had up to three sub-themes (Table 3). Results are reported in accordance with the Standards for Reporting Qualitative Research (SRQR) guidelines [27] and the COnsolidated criteria for REporting Qualitative research (COREQ) checklist.

\section{Patient and Public involvement}

Administrators and coordinating physicians from 14 nursing homes were actively involved in collecting and anonymizing study data from their residents/patients. During the exploratory phase of research (December 2020 to January 2021), any feedback from qualitative study site administrators was included in the study protocol. During data collection (January to February 2021), the research methodology was discussed with MSF nurses and facilities staff and adapted to each nursing home's context and caregiver guidance. At the beginning of each IDI, caregivers and residents were encouraged to further participate in the research by contacting the lead investigator with any suggestions. In the reporting phase (from the 1st March to June 2021), internal reporting was sent to interviewees who wanted to be contacted for this purpose. This report was sent to prominent political COVID-19 crisis management actors (such as the French Ministry of Health). A summary letter will be brought to resident study participants and facility staff to inform them of the results and gather their comments on possible follow-up.

\section{Ethics}

This study received approval from the MSF Ethical Review Board (ERB) and the Commission Nationale de I'Informatique et des Libertés (CNIL) in France. Patient data and qualitative observations were fully anonymized. All study procedures were in line with the Declaration of Helsinki.

\section{RESULTS}

22 nursing homes were originally included in the study, though data was available for only 14 of them (the others did not send data in time for analysis or the data were not electronically recorded). The 14 participating nursing facilities were largely state supported entities (79\%) with an average of 68 residents (median=65; IQR: 
medRxiv preprint doi: https://doi.org/10.1101/2021.12.12.21267681; this version posted December 14, 2021. The copyright holder for this preprint (which was not certified by peer review) is the author/funder, who has granted medRxiv a license to display the preprint in perpetuity.

It is made available under a CC-BY-NC-ND 4.0 International license .

190 58-73). Results varied considerably from one nursing home to another. COVID-19 outbreak duration averaged

19139 days (median=40; IQR: 30-50 days) while Infected residents' individual COVID-19 episodes averaged 24 days

192 (median=30; IQR: 14-51 days). The average attack rate was 39\% (median=39\%; IQR: 29\%-54\%) among staff and

$19361 \%$ (median=60\%; 50\%-73\%) among residents. One-fifth (median=20\%; IQR: 17\%-23\%) of the residents who

194 were infected ultimately succumbed to COVID-19 and its complications. The mean Average Weighted

195 Autonomy Score (AWAS) was 770 (median=763; IQR: 722-804) and the average staff-to-resident ratio was 0.82

196 (median=0.86; IQR: 0.72-0.90). The average time to universal masking policies being implemented was 9.6 days

197 (median=6.5; IQR: 2-15 days) and average time until a facility was bolstered with MSF support (staff or

198 resources) was 17.5 days (median=15; IQR: 13-28 days). (Appendix 4).

\section{Patient Risk factors}

200 Retrospective COVID-19 data were obtained for 14 nursing homes, finding 585 COVID-19 cases among 930

201 residents $(61 \%$ attack rate) (Table 1$)$. Cases were mostly women $(78 \%)$ who were $>85$ years old $(68 \%)$.

202 Individual Autonomy Scores (IAS) were low $(<2)$ in a majority of cases $(60 \%)$, indicating a very low-level of

203 autonomy overall. One-fifth (21\%) of cases were transferred to a hospital, while half (46\%) were put on oxygen

204 therapy. One-tenth (12\%) of COVID-cases received palliative care, and nearly one-quarter (22\%) died. Failure-

205 to-Thrive Syndrome was diagnosed in nearly one-quarter (23\%) of COVID-positive residents. At least one other

206 comorbidity was found in over half $(61 \%)$ of infected residents. AWAS, nursing home size, and staff-to-resident

207 ratios were all strongly correlated, as were time-related variables (time until external MSF support was

208 received, time until universal masking policies were applied, and duration of COVID episode) (Table 1).

209 Table 1. Univariate Analysis of Nursing Home Resident and Facility Data, Provence and Occitania Provinces, 210 France, 2021 
medRxiv preprint doi: https://doi.org/10.1101/2021.12.12.21267681; this version posted December 14, 2021. The copyright holder for this preprint (which was not certified by peer review) is the author/funder, who has granted medRxiv a license to display the preprint in perpetuity.

It is made available under a CC-BY-NC-ND 4.0 International license .

214 Univariate analysis using Cox modelling (Table 1) and Kaplan-Meier estimations (Figure 1) suggested that

215 individual characteristics like gender (log rank $p<0.001)$ and $\mid A S(p=0.008)$ were associated with COVID-19

216 mortality, while age and specific comorbidities were not. Survival curves also suggested that facility

217 characteristics like low AWAS ( $p<0.001)$, the absence of a permanent physician on site $(<0.001)$, larger nursing

218 home size (>70 residents) $(p=0.036)$, and a high staff attack rate $(p=0.025)$ were also associated with resident

219 mortality. Predictably, hospitalization $(p<0.001)$, palliative care $(p<0.001)$, and oxygen therapy $(p<0.001)$ were

220 all strongly correlated with the risk of death, as was the presence of FTTS $(p<0.001)$ and the presence of more

221 than 4 co-morbidities (risk increased with the number of co-morbidities present, $\mathrm{p}=0.045$ ). Additional Kaplan-

222 Meier Curves for non-significant factors can be found in the supplementary information (Appendix 5).

223 Multilevel Cox Hazard modelling highlighted mortality associated factors adjusted for potential confounders

224 (Figure 2). Those at highest risk of death were men (HR=1.78; IC95: $1.18-2.70 ; \mathrm{p}=0.006)$ with an FTTS diagnosis

$225(\mathrm{HR}=4.04 ; \mathrm{IC95}: 1.93-8.48 ; \mathrm{p}<0.001)$ in facilities with delayed implementation of universal masking policies

$226(\mathrm{HR}=1.05 ; \mathrm{IC95}: 1.02-1.07 ; \mathrm{p}<0.001)$. The lowest mortality risk was found in residents of facilities with a partial

$227(H R=0.30 ;$ IC95: $0.18-0.51 ; p<0.001)$ or full-time physician on staff $(H R=0.20 ;$ IC95: $0.08-0.53 ; p=0.001)$, with

228 individual AES scores $>3(H R=0.38 ; \mathrm{IC} 95: 0.16-0.89 ; \mathrm{p}=0.026)$. Noticeably, higher AWAS (a proxy for staff-to-

229 resident ratios and a nursing home's overall means) was associated with a lower risk of death (HR=0.99; IC95:

$230 \quad 0.99-1.00 ; p=0.020$ ) (Table 2). Sensitivity analysis can be found in the supplementary information (Appendix 6).

231 Table 2. Multivariate Cox Hazard adjusted analysis of mortality associated factors in French nursing facilities,

232 Provence and Occitania provinces, 2021 (Information Criteria: $\mathrm{AIC} \mathrm{C}^{*}=1171 ; \mathrm{BIC}=1226$ ) 
medRxiv preprint doi: https://doi.org/10.1101/2021.12.12.21267681; this version posted December 14 , 2021. The copyright holder for this preprint (which was not certified by peer review) is the author/funder, who has granted medRxiv a license to display the preprint in perpetuity.

It is made available under a CC-BY-NC-ND 4.0 International license .

234 Figure 2. Final Cox Model: Forest Plot of mortality associated factors in French nursing facilities, Provence and

235 Occitania provinces, 2021

236 Qualitative Results

237 The qualitative approach richly described interviewees' lived experiences during the COVID-19 crisis, revealing

238 difficult-to-quantify social influences on the outbreak's evolution and impact. Three significant themes

239 emerged from our discussions (Table 3).

240 Structural, Chronic Neglect of Nursing Homes

241 Staff members described a long-standing lack of physicians in nursing homes, exacerbated by lockdowns and

242 growing medical needs during a period of rising COVID-19 infections. One nurse explained, "the nursing home

243 was almost like a hospital ward at one point...There was more supervision [needed], more care...We didn't have

244 the staff to do all that." All groups of interviewees emphasized that working in precarious and understaffed

245 conditions was a substantial difficulty that became a critical risk during the COVID-19 outbreak and

246 compromised the response. Assistant nurses described extremely challenging working conditions: "When they

247 ask you to help 13 people to bath before noon, you don't work well." This situation was worse during the

248 second pandemic wave when, as one psychologist explained, "no one counted the hours. We had to be there,

249 we put our private lives on hold, but it was important to do it." All directors described a structural lack of a

250 "permanent medical presence" and the need of a "strict staffing ratio."

\section{Top-down Crisis Management}

252 Personnel highlighted the "top-down" approach of French health authorities, including a lack of communication

253 and time-consuming processes for staff and administrators alike, "The ARS [Regional Health Authorities] have

254 been absent during the whole crisis. (...) Since March, I haven't seen the authorities giving us any support, nor

255 any real help, except for claiming statistics back." These officials worked far from the frontline environment of a

256 nursing home and were removed from the suffering of residents and staff. As a result, it was felt that they encouraged ill-informed, unrealistic, and inconsistent crisis-response measures: limiting contact with residents,

258 confining them to their (small) rooms, abruptly relocating them in new rooms (very disturbing for them) or 259 even physically restraining residents in distress. A psychologist described how "some people had to be 
It is made available under a CC-BY-NC-ND 4.0 International license .

260

261

262

263

264

265

266

267

268

269

270

uprooted from their rooms" where they had "spatial-temporal and autobiographical markers", while others "had to be restrained" by assistant nurses. All of these were deeply disheartening to staff and residents, creating feelings of shame and guilt among caregivers and the potential for cognitive disorders among residents. A resident explained that "it was hard, staying in the room for a whole day, without going out," and that "anyone would become nuts!" Weak crisis response mechanisms also manifested as poor prevention measures (a lack of universal masking requirements initially, facemask shortages during the first wave), lack of state medical relief staff, and such an extreme lack of preparedness that assistance from a non-state humanitarian actor like MSF was needed. As a director told us, calling MSF, a disaster-response organization "showed what a disaster we were experiencing."

\section{Counterproductive Effects of Lockdowns}

Finally, participants described the counterproductive effects of lockdowns, including negative medical outcomes and even violence. Physiotherapists described "a decline in motor skills, but even more in cognitive skills" and "completely accelerated failure-to-thrive syndrome" which corroborates other descriptions of "bedridden patients, depressive states, failure-to-thrive" because "the residents haven't gone out for a year." Participants were discouraged that lessons from the first pandemic wave did not translate into better preparedness and smoother, more nuanced, and less restrictive lockdown policies during the second. Despite feeling secure in their nursing home environment during the pandemic period, interviews with residents revealed the depth of their dislike for the extreme physical and social isolation they faced while alone in their rooms, especially when facilities' social activities, family visits, and outings were suspended or strictly supervised with social distancing measures. Extreme fatigue occurred after a year of lockdown and social restrictions, as one nursing home's 90 -year-old resident explained "if we could go out, we would bear it better." Since facility administrators were urged to follow the ARS recommendations, only a few directors or staff were willing to soften lockdown measures, allow family visits, or take residents' end-of-life wishes or needs for social interaction into account.

These interviews show some overlap with the risk factors that were highlighted in the quantitative data (mortality risks linked to understaffing, the absence of a permanent staff physician, low staff-to-resident ratios, lockdowns linked to FTTS). Other qualitative factors associated with better pandemic management also 
medRxiv preprint doi: https://doi.org/10.1101/2021.12.12.21267681; this version posted December 14, 2021. The copyright holder for this preprint (which was not certified by peer review) is the author/funder, who has granted medRxiv a license to display the preprint in perpetuity.

It is made available under a CC-BY-NC-ND 4.0 International license .

287 appeared in interviews, such as reliable communication with local health authorities, the presence of an

288 effective national health strategy, and collaboration with other medical sectors. 
Table 3. Representative quotes for the 3 themes 
medRxiv preprint doi: https://doi.org/10.1101/2021.12.12.21267681; this version posted December 14, 2021. The copyright holder for this preprint (which was not certified by peer review) is the author/funder, who has granted medRxiv a license to display the preprint in perpetuity.

It is made available under a CC-BY-NC-ND 4.0 International license .

290

291

292

293

294

295

296

297

298

299

300

301

302

303

304

305

306

307

308

309

310

311

312

313

314

315

\section{DISCUSSION}

Our study is the first mixed-methods investigation of nursing homes during the COVID-19 pandemic in France, and one of the first in Europe. MSF staff's close, in-person work with these care facilities gave investigators privileged access during a challenging period and lead to particularly rich interviews. This lies in contrast to most other qualitative investigation of the geriatric population during the COVID period, which have usually been conducted remotely or via surrogates (caregiving staff or family members), without being able to interview residents themselves. These results show clearly that the second wave looked largely similar to the first wave in French nursing homes, in both response and impact, and that these facilities were not sufficiently prepared and supported when facing subsequent threats to their vulnerable tenants.

Nursing home data is not routinely collected by French national health information services because residents are considered to "live at home." Thus, considering how difficult it is to access even the most basic data from these facilities (such as number of cases or deaths), we managed to construct a large dataset containing detailed information about COVID-19 cases, which affected 30\% of all residents in the 14 participating nursing homes. The study also allowed a thorough examination of COVID-19 as experienced by the staff and residents who most suffered from the pandemic. To the best of our knowledge, French crisis management measures during the second pandemic wave were never informed by qualitative data. In this study, patients' risk factors could be explored in relation to influential social and structural determinants of health, such as understaffing, strict lockdown measures, isolation from other medical actors/lack of medical support or the top-down and bureaucratic crisis management by health authorities.

Our multivariate analyses confirmed mortality trends seen in other settings. Similar to other studies, we found that men died more often despite their being a minority of nursing home residents, and that residents' autonomy was a strong factor in their survival, with those who were more reliant on staff for daily support most likely to succumb to their disease [8-10, 28-32]. Living with multiple comorbidities (especially diabetes and dementia) was also strongly predictive of COVID-mortality in our group $[8,10,28-32]$. The negative effects of understaffing (seen as sick leave or AWAS in our data) were similar to those reported in the United States [8], Spain [32], and the United Kingdom [33-34], and constitute a vicious cycle: during periods of high 
316 transmission, more staff needed sick leave. Yet, the medical and staffing needs of residents were

317 simultaneously surging, forcing many sick (and infectious) caregivers back into the workplace. The cycle was

318 compounded by the destructive effects that an enormous workload and an anxiety-producing work

319 environment is known to have on caregivers' wellbeing [12, 18, 20, 21, 36].

320 The efficacy of universal masking to prevent respiratory disease is well established [37,38], though we were not 321 able to measure the impact of staff/resident masking because mask mandates were often put in place at the 322 same time that extra resources and support from MSF arrived and bolstered the nursing facility overall. 323 Nevertheless, our results do suggest that higher transmission and case fatality were associated with delays in 324 mandatory mask requirements for staff, confirming the utility of these rules in uniquely vulnerable and high325 risk nursing home settings. The facemask issue is not easy, however, in a nursing home context. The health 326 benefits of masking have trade-offs with other social needs: care home residents may live with hearing or 327 cognitive disorders, and masking may prevent voice and facial recognition or communication. The absence of 328 others' daily smiles or expression may have led to cognitive decline, a point that has been shown in previous research and was emphasized in our interviews with caregivers, managers, and residents alike [39, 40].

330 Finally, the benefit of confining residents to their rooms is strongly questioned by these results. While such 331 measures undeniably reduce virus transmission among residents [6-10, 14-15, 33, 37-38, 41-43]; the 332 consequences for their mental health and nutritional status have also been shown to be considerable [12, $33313,20-24,36,44-48]$. Strict lockdowns in our cohort were associated with higher FTTS incidence, triggered by 334 individuals' difficult living conditions over multiple months (the long duration of the crisis, an anxiety-provoking 335 atmosphere, social isolation, other residents' deaths, etc.). We found a strong statistical association between 336 COVID-19 case fatality and FTTS diagnoses, a result that was triangulated by qualitative interview data and is 337 consistent with other research from France [41], the United Kingdom [42], Finland [46], Spain [48,50], Italy [49], 338 and the United States [47].

\section{Limitations}

340 Our study is limited by the fact that study site selection was not random but was instead steered by discussions 341 with MSF. Moreover, since MSF targeted mostly struggling nursing homes, the study included only a small number that did not have major outbreaks (or contained their outbreaks early). As a result, comparing these 
medRxiv preprint doi: https://doi.org/10.1101/2021.12.12.21267681; this version posted December 14, 2021. The copyright holder for this preprint (which was not certified by peer review) is the author/funder, who has granted medRxiv a license to display the preprint in perpetuity.

It is made available under a CC-BY-NC-ND 4.0 International license .

343 facilities to others in Provence and Occitania (or France) should be made with care. Participant selection was

344 biased by the fact that only residents who were fully capable of interacting with investigators and were able to

345 give informed consent could be interviewed, thus excluding anyone with major cognitive disorders (a relatively

346 frequent condition in nursing homes). Quantitative data were neither exhaustive nor always electronically

347 recorded. Associations between COVID-19 deaths and FTTS were complicated by the co-morbidities that many

348 residents also lived with, though adjusted analysis attempted to control for potential confounding.

\section{CONCLUSION}

350 These results raise questions about French health authorities' approach to managing the second wave of the 351 COVID-19 pandemic, as seen through the lens of those living through the crisis. If institutional management of 352 older ager, loss of autonomy and end of life is a chronic issue for a long time in France, solutions exist to support nursing homes in times of acute crisis. Future debates about pandemic response in this setting should

354 take into account things like the social needs of residents, understaffing as a risk factor for higher COVID-

355 related deaths, and should refine general health policies and prevention measures in nursing homes.

356 Moreover, once an outbreak has occurred, tough questions must be asked: Are restrictive measures for all 357 residents worth the personal and mental health toll? How can facilities improve residents' end-of-life 358 conditions in a controlled, safe way that will allow them (and their families) dignity and care? Is this reasonable 359 to do if it involves a modicum of increased risk exposure for the facility overall? These results remind us that 360 effective COVID-19 response should be context-adapted, patient-centered, and humane. 
medRxiv preprint doi: https://doi.org/10.1101/2021.12.12.21267681; this version posted December 14, 2021. The copyright holder for this preprint (which was not certified by peer review) is the author/funder, who has granted medRxiv a license to display the preprint in perpetuity.

It is made available under a CC-BY-NC-ND 4.0 International license.

FIGURES

363

364 Figure 1 Legend: On the $X$ axis: Number of weeks from Oct $15^{\text {th }}, 2020$; On the $Y$ axis: probability of resident'survival.

365 Figure 1 Title: Likelihood of survival by resident and nursing facility characteristic, Univariate (Kaplan-Meier)

366

Analysis, Provence and Occitania Provinces, France, 2021

367

Figure 2 Legend: $(H R>1)$, full-lines in green for protective factors ( $H R<1)$ and dashed-lines in grey for $\mathrm{Cl95 \%}$ of non-significant factors.

368 Figure 2 title: Final Cox Model: Forest Plot of mortality associated factors in French nursing facilities, Provence

369 and Occitania provinces, 2021

370

371

372 
medRxiv preprint doi: https://doi.org/10.1101/2021.12.12.21267681; this version posted December 14 , 2021. The copyright holder for this preprint (which was not certified by peer review) is the author/funder, who has granted medRxiv a license to display the preprint in perpetuity.

It is made available under a CC-BY-NC-ND 4.0 International license .

373

374

375

376

377

378

379

380

381

382

384

385

386

\section{CONTRIBUTORS}

$\mathrm{CM}, \mathrm{TR}, \mathrm{MD}, \mathrm{TL}$ and EG conceived the study (literature search, study design, etc). MD, SF, TR, CM, TL and EG developed the study protocol. MD performed field data collection (qualitative interviews) and SF collected epidemiological data. TR and SF performed data management and statistical data analysis. MD performed interview transcription and qualitative analysis. MD and TR performed literature search and wrote the first version of the manuscript. TR and EG verified the underlying data and performed additional analyses. All authors interpreted the results, contributed to writing the manuscript, and approved the final version for submission.

\section{ACKNOWLEDGMENTS}

First and foremost, authors are very grateful and thank Janet Ousley for her help on article editing. Authors also thank Marie Thomas, Tommaso Fabbri, Klaudia Porten, Michel-Olivier Lacharité, Marc Gastelly-Etchegorry, and the whole MSF team in the field. This study would not have been possible without the collaboration of the nursing home managers, staff, and residents. A very special thanks go to each and every one of them.

\section{COMPETING INTERESTS}

Authors declare having no competing interests.

\section{FUNDING AND ALL OTHER REQUIRED STATEMENTS}

This study was entirely funded by Médecins Sans Frontières-France.

\section{REFERENCES}

1. Etude DREES. "En 2020, trois Ehpad sur quatre ont eu au moins un résident infecté par la Covid19".https://drees.solidarites-sante.gouv.fr/sites/default/files/2021-07/ER1196.pdf

2. Comas-Herrera, A., Zalakain, J., Lemmon et al. (2021). Mortality associated with COVID-19 in care homes: international evidence. Last updated: 1st February, 2021. https://tccovid.org/2020/04/12/mortality-associated-with-covid-19-outbreaks-in-care-homes-earlyinternationalevidence/

3. Belmin, J., Um-Din, N., Donadio et al.(2020). Coronavirus Disease 2019 Outcomes in French Nursing Homes That Implemented Staff Confinement With Residents. JAMA Network Open, 3(8), e2017533. https://doi.org/10.1001/jamanetworkopen.2020.17533

4. Blain, H., Rolland, Y., \& Tuaillon et al. (2020). Efficacy of a Test-Retest Strategy in Residents and Health Care Personnel of a Nursing Home Facing a COVID-19 Outbreak. Journal of the American Medical Directors Association, January. J Am Med Dir Assoc. 2020 Jul;21(7):933-936. doi: 10.1016/j.jamda.2020.06.013. 
It is made available under a CC-BY-NC-ND 4.0 International license .

404

405

406

407

408

409

410

411

412

413

414

415

416

417

418

419

420

421

422

423

424

425

426

427

428

429

430

431

432

433

434

435

436

437

438

439

440

441

442

443

444

445

446

447

448

449

450

451

452

5. Bernadou, A., Bouges, S., Catroux et al.(2021). High impact of COVID-19 outbreak in a nursing home in the Nouvelle-Aquitaine region, France, March to April 2020. BMC Infectious Diseases, 21(1), 1-6. https://doi.org/10.1186/s12879-021-05890-6

6. Shallcross, L., Burke, D., Abbott et al.(2021). Factors associated with SARS-CoV-2 infection and outbreaks in long-term care facilities in England : a national cross-sectional survey. The Lancet Healthy Longevity, 2(3), e129-e142. https://doi.org/10.1016/s2666-7568(20)30065-9

7. Gopal, R., Han, X., \& Yaraghi, N. (2021). Compress the curve: A cross-sectional study of variations in COVID-19 infections across California nursing homes. BMJ Open, 11(1). https://doi.org/10.1136/bmjopen-2020-042804

8. Dutey-Magni PF, Williams H, Jhass A et al (2021). COVID-19 infection and attributable mortality in UK care homes: cohort study using active surveillance and electronic records (March-June 2020). Age Ageing. 2021 Jun 28;50(4):1019-1028. doi: 10.1093/ageing/afab060.

9. Burton, J. K., Bayne, G., Evans et al.(2020). Evolution and effects of COVID-19 outbreaks in care homes : a population analysis in 189 care homes in one geographical region of the UK. The Lancet Healthy Longevity, 1(1), e21-e31. https://doi.org/10.1016/s2666-7568(20)30012-x

10. Rutten, J. J. S., van Loon, A. M., van Kooten, J. et al. (2020). Clinical Suspicion of COVID-19 in Nursing Home residents : symptoms and mortality risk factors. Journal of the American Medical Directors Association, 1-13. https://doi.org/10.1016/i.jamda.2020.10.034

11. Mas Romero, M., Avendaño Céspedes, A., Tabernero Sahuquillo et al.(2020). COVID-19 outbreak in long-term care facilities from Spain. Many lessons to learn. PloS One, 15(10), e0241030. https://doi.org/10.1371/journal.pone.0241030

12. Sriram, V., Jenkinson, C., \& Peters, M. (2021). Impact of Covid-19 restrictions on carers of persons with dementia in the UK - A qualitative study. Age and Ageing, 1-10. $2021 \mathrm{Jul} 5$ :afab156. doi: 10.1093/ageing/afab156.

13. Mo, S., \& Shi, J. (2020). The psychological consequences of the Covid-19 on residents and staff in nursing homes. Work, Aging and Retirement, 6(4), 254-259. https://doi.org/10.1093/workar/waaa021

14. Giri, S., Chenn, L. M., \& Romero-Ortuno, R. (2021). Nursing homes during the COVID-19 pandemic: a scoping review of challenges and responses. European Geriatric Medicine, 0123456789.

https://doi.org/10.1007/s41999-021-00531-2

15. Dykgraaf, S. H., Matenge, S., Desborough, J. et al. (2021). Protecting Nursing Homes and Long Term Care Facilities From Covid-19: a Rapid Review of International Evidence. Journal of the American Medical Directors Association, August. https://doi.org/10.1016/i.jamda.2021.07.027

16. Lefèvre, B., Tondeur, L., Madec, Y et al (2021). Beta SARS-CoV-2 variant and BNT162b2 vaccine effectiveness in long-term care facilities in France. The Lancet Healthy Longevity, 7568(21), 21-23. https://doi.org/10.1016/s2666-7568(21)00230-0

17. Blain H, Tuaillon E, Gamon L et al. (2021). Antibody response after one and two jabs of the BNT162b2 vaccine in nursing home residents: The CONsort-19 study. Allergy. $2021 \mathrm{Jul}$ 19:10.1111/all.15007. doi: 10.1111/all.15007. Epub ahead of print. PMID: 34286856; PMCID: PMC8441741.

18. Sarabia-Cobo C, Pérez V, de Lorena P et al.(2021). Experiences of geriatric nurses in nursing home settings across four countries in the face of the COVID-19 pandemic. J Adv Nurs. 2021 Feb;77(2):869878. doi : 10.1111/jan.14626. Epub 2020 Nov 22. PMID : 33150622.

19. Belmin, Joël, Um Din, Nathavy, Pariel, Sylvie et al. (2020). " Confinement du personnel d'Ehpad avec les résidents : une solution contre le Covid-19 ? ", Gériatrie et Psychologie Neuropsychiatrie du Vieillissement, Vol $\quad 18, \quad n^{\circ} 3 . \quad$ https://www.je.com/fr/revues/gpn/edocs/confinement du personnel dehpad avec les residents une solution contre le covid $19 \quad 31$ 8443/article.phtml

20. Kaelen S, van den Boogaard W, Pellecchia U et al. (2021) How to bring residents' psychosocial wellbeing to the heart of the fight against Covid-19 in Belgian nursing homes-A qualitative study. PLOS ONE 16(3) : e0249098. https://doi.org/10.1371/journal.pone.0249098 
It is made available under a CC-BY-NC-ND 4.0 International license .

21. Lood, Q., Haak, M., \& Dahlin-, S. (2021). Everyday life in a Swedish nursing home during the COVID-19 pandemic]: a qualitative interview study with persons 85 to 100 years. BMJ Open, October 2020 . https://doi.org/10.1136/bmiopen-2020-048503

22. Rutten, J. E. R., Backhaus, R., PH Hamers, J. et al. (2021). Working in a Dutch nursing home during the COVID-19 pandemic: Experiences and lessons learned. Nursing Open, May, 1-10. https://doi.org/10.1002/nop2.970

23. Leontjevas, R., Knippenberg, I. A. H., Smalbrugge et al.(2020). Challenging behavior of nursing home residents during COVID-19 measures in the Netherlands. Aging and Mental Health, $0(0), 1-6$. https://doi.org/10.1080/13607863.2020.1857695

24. Verbeek, H., Gerritsen, D. L., Backhaus, R. et al. (2020). Allowing Visitors Back in the Nursing Home During the COVID-19 Crisis : A Dutch National Study Into First Experiences and Impact on Well-Being. Journal of the American Medical Directors Association, 21(January), 900-904. https://doi.org/10.1016/i.jamda.2020.06.020

25. Austin PC. A Tutorial on Multilevel Survival Analysis: Methods, Models and Applications. Int Stat Rev. 2017 Aug;85(2):185-203. doi: 10.1111/insr.12214.

26. Adler, P., Adler, P. (1987), Membership Roles in Field Research, Sage Publications, Newbury Park, CA, $95 \mathrm{p}$.

27. O'Brien BC, Harris IB, Beckman TJ et al. Standards for reporting qualitative research: a synthesis of recommendations. Acad Med. 2014 Sep;89(9):1245-51. doi: 10.1097/ACM.0000000000000388. PMID: 24979285.

28. Suñer, C., Ouchi, D., Mas, M.A. et al. (2021). A retrospective cohort study of risk factors for mortality among nursing homes exposed to COVID-19 in Spain. Nature Aging, 1(July). https://doi.org/10.1038/s43587-021-00079-7

29. Couderc, A.-L., Correard, F., Hamidou, Z. et al. (2021). Factors Associated With COVID-19 Hospitalizations and Deaths in French Nursing Homes. Journal of the American Medical Directors Association, January.

30. Martinsson, L., Strang, P., Bergström, J. et al. (2021). Dying from COVID-19 in nursing homes-sex differences in symptom occurrence. BMC Geriatrics, 21(1), 1-8. https://doi.org/10.1186/s12877-02102228-4

31. Meis-Pinheiro, U., Lopez-Segui, F. et al.(2021). Clinical characteristics of COVID-19 in older adults. A retrospective study in long-term nursing homes in Catalonia. Plos One, 16(7), e0255141. https://doi.org/10.1371/journal.pone.0255141

32. Bielza, R., Sanz, J., Zambrana, F., et al (2020). Clinical Characteristics, Frailty, and Mortality of Residents With COVID-19 in Nursing Homes of a Region of Madrid. Journal of the American Medical Directors Association, January.

33. Candel, F. J., Barreiro, P., San Román, J. et al. (2021). The demography and characteristics of SARS-CoV2 seropositive residents and staff of nursing homes for older adults in the Community of Madrid: the SeroSOS study. Age and Ageing, 50(4), 1038-1047. https://doi.org/10.1093/ageing/afab096

34. Landes, S. D., Turk, M. A., Damiani, M. R. et al. (2021). Risk factors associated with covid-19 outcomes among people with intellectual and developmental disabilities receiving residential services. JAMA Network Open, 4(6), 1-11. https://doi.org/10.1001/jamanetworkopen.2021.12862

35. Roselló, A., Barnard, R. C., Smith, D. R. M. et al. (2021). Impact of non-pharmaceutical interventions on SARS-CoV-2 outbreaks in English care homes[: a modelling study Members of the Centre for Mathematical Modelling of Infectious Diseases ( CMMID ) COVID-19 modelling working group ( random order ): MedRxiv, 1-21.

36. Hugelius, K., Harada, N., \& Marutani, M. (2021). Consequences of visiting restrictions during the COVID-19 pandemic: An integrative review. International Journal of Nursing Studies, January.

37. McGarry BE, Grabowski DC, Barnett ML. Severe staffing and personal protective equipment shortages faced by nursing homes during the COVID-19 pandemic. Health Aff (Millwood) 2020;39:1812e1821

38. Li, Y., Fang, F., \& He, M. (2021). Exploring the N95 and Surgical Mask Supply in U.S. Nursing Homes During COVID-19. Journal of Applied Gerontology, 40(3), 257262. https://doi.org/10.1177/0733464820969015 
It is made available under a CC-BY-NC-ND 4.0 International license .

39. Marler H, Ditton A. "I'm smiling back at you" : Exploring the impact of mask wearing on communication in healthcare. Int J Lang Commun Disord. 2021 Jan;56(1):205-214. doi : 10.1111/14606984.12578. Epub 2020 Oct 10. PMID : 33038046; PMCID : PMC7675237.

40. van Wassenhove V, Grant KW, Poeppel D. Visual speech speeds up the neural processing of auditory speech. Proc Natl Acad Sci U S A. 2005 Jan 25;102(4):1181-6. doi : 10.1073/pnas.0408949102. Epub 2005 Jan 12. PMID : 15647358 ; PMCID : PMC545853.

41. Canouï-poitrine, F., Rachas, A., \& Thomas, M. (2021). Magnitude, change over time, demographic characteristics and geographic distribution of excess deaths among nursing home residents during the first wave of COVID-19 in France : a nationwide cohort study. MedRxiv, 1-23.

42. Jeffery-Smith, A., Dun-Campbell, K., Janarthanan, R. et al.(2021). Infection and transmission of SARSCoV-2 in London care homes reporting no cases or outbreaks of COVID-19: prospective observational cohort study, England 2020. The Lancet Regional Health - Europe, 3(January 2020), 100038. https://doi.org/10.1016/i.lanepe.2021.100038

43. Mehta, H. B., Li, S., \& Goodwin, J. S. (2021). Risk Factors Associated With SARS-CoV-2 Infections, Hospitalization, and Mortality Among US Nursing Home Residents. JAMA Network Open, 4(3), e216315. https://doi.org/10.1001/iamanetworkopen.2021.6315

44. Levere, M., Rowan, P., \& Wysocki, A. (2021). The Adverse Effects of the COVID-19 Pandemic on Nursing Home Resident Well-Being. Journal of the American Medical Directors Association, January.

45. Van der Roest HG, Prins M, van der Velden C et al. (2020). The Impact of COVID-19 Measures on WellBeing of Older Long-Term Care Facility Residents in the Netherlands. J Am Med Dir Assoc. 2020 Nov;21(11):1569-1570. doi : 10.1016/j.jamda.2020.09.007. Epub 2020 Sep 10. PMID : 33036911; PMCID : PMC7833500.

46. Paananen, J., Rannikko, J., \& Harju, M. (2021). The impact of Covid-19-related distancing on the wellbeing of nursing home residents and their family members: a qualitative study. International Journal of Nursing Studies Advances, January.

47. Huda ELSheikh, H. ELSheikh, H. Oh, A. Bender et al.(2021). Examining the Effects of Modified Recreational Activities on the Mental Health of Nursing Home Residents During COVID-19,Journal of the American Medical Directors Association, Volume 22, Issue 3,2021. https://doi.org/10.1016/j.jamda.2021.01.026.

48. Araújo, M. P. D., Nunes, V. M. de A., Costa, L. de A. et al. (2021). Health conditions of potential risk for severe Covid-19 in institutionalized elderly people. Plos One, 16(1), e0245432. https://doi.org/10.1371/journal.pone.0245432

49. De Vito, A., Fiore, V., Princic, E. et al. (2021). Predictors of infection, symptoms development, and mortality in people with SARS-CoV-2 living in retirement nursing homes. PloS One, 16(3 March), 1-14. https://doi.org/10.1371/journal.pone.0248009

50. Pérez-Rodríguez, P., Díaz de Bustamante, M., Aparicio Mollá, S. et al. (2021). Functional, cognitive, and nutritional decline in 435 elderly nursing home residents after the first wave of the COVID-19 Pandemic. European Geriatric Medicine, 0123456789. https://doi.org/10.1007/s41999-021-00524-1 


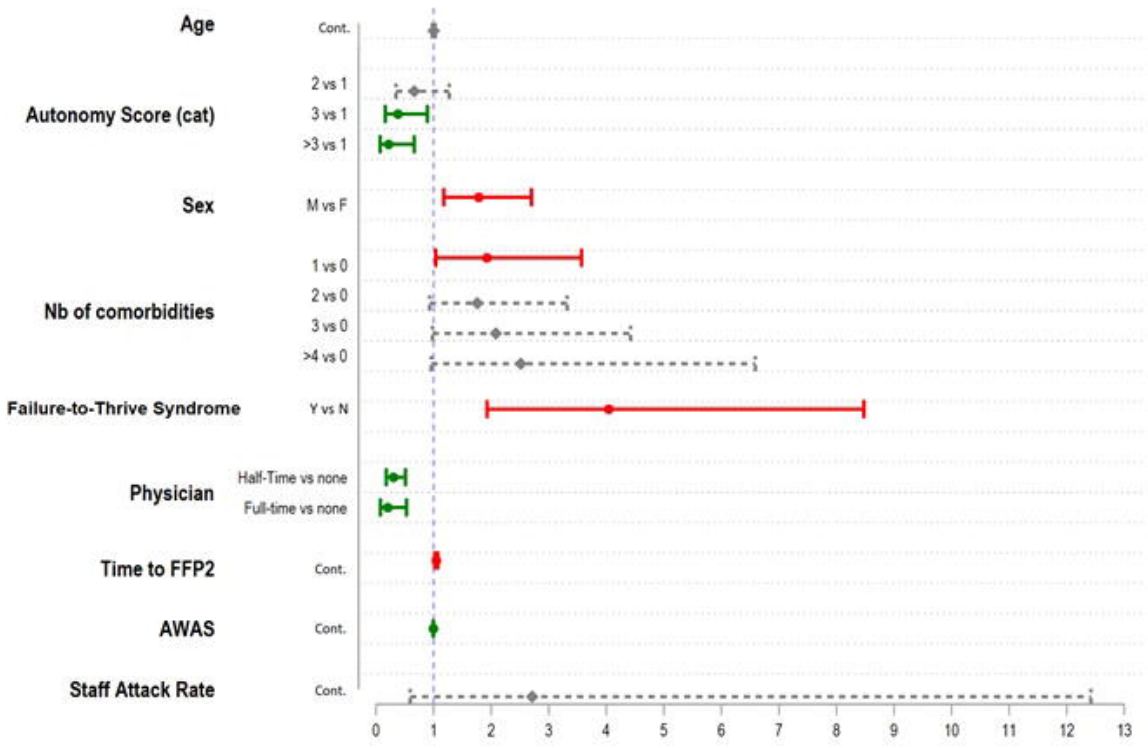


medRxiv preprint doi: https://doi.org/10.1101/2021.12.12.21267681; this version posted December 14, 2021. The copyright holder for this preprint (which was not certified by peer review) is the author/funder, who has granted medRxiv a license to display the preprint in perpetuity.

It is made available under a CC-BY-NC-ND 4.0 International license .

Table 1. Univariate Analysis of Nursing Home Resident and Facility Data, Provence and Occitania Provinces, France, 2021

\begin{tabular}{|c|c|c|c|c|c|c|c|c|}
\hline & & \multicolumn{2}{|c|}{$\begin{array}{c}\text { Deceased } \\
\mathrm{N}=131(22 \%) \\
\end{array}$} & \multicolumn{2}{|c|}{$\begin{array}{c}\text { Survived } \\
N=454(78 \%)\end{array}$} & \multirow[t]{2}{*}{$\begin{array}{c}\text { Hazard Ratio } \\
\text { (non adj.) }\end{array}$} & \multirow[t]{2}{*}{ IC 95\% } & \multirow[t]{2}{*}{$\begin{array}{l}\text { Log-Rank } \\
\text { Test p-value }\end{array}$} \\
\hline & & $n$ & $\%$ & $n$ & $\%$ & & & \\
\hline \multicolumn{9}{|c|}{ Individual Data } \\
\hline \multirow{2}{*}{ Gender } & Female & 89 & 19.5 & 368 & 80.5 & Ref & & \multirow{2}{*}{$<0.001$} \\
\hline & Male & 42 & 33.1 & 85 & 66.9 & $2.06 * * *$ & $1.41-3.02$ & \\
\hline \multirow{4}{*}{ Age (cat.) } & $65-75 y$ & 10 & 20 & 40 & 80 & Ref & & \multirow{4}{*}{0.971} \\
\hline & $75-85 y$ & 29 & 22 & 103 & 78 & 1.14 & $0.74-1.76$ & \\
\hline & $85-95 y$ & 65 & 23 & 218 & 77 & 1.19 & $0.62-2.28$ & \\
\hline & $>95 \mathrm{y}$ & 27 & 22.7 & 92 & 77.3 & 1.14 & $0.67-1.93$ & \\
\hline \multirow{6}{*}{ Autonomy Score } & 1 & 33 & 29.2 & 80 & 70.8 & Ref & & \multirow{6}{*}{0.008} \\
\hline & 2 & 62 & 26.2 & 175 & 73.8 & 0.96 & $0.58-1.59$ & \\
\hline & 3 & 24 & 20.9 & 91 & 79.1 & 0.71 & $0.35-1.45$ & \\
\hline & 4 & 11 & 10.9 & 90 & 89.1 & $0.38 * * *$ & $0.19-0.75$ & \\
\hline & 5 & 0 & 0 & 11 & 100 & $0.00 * * *$ & $0.00-0.00$ & \\
\hline & 6 & 1 & 14.3 & 6 & 85.7 & 0.52 & $0.08-3.55$ & \\
\hline \multirow{4}{*}{ Autonomy Score (cat.) } & $\mathrm{AES}=1$ & 33 & 29.2 & 80 & 70.8 & Ref & & \multirow{4}{*}{$<0.001$} \\
\hline & 2 & 62 & 26.2 & 175 & 73.8 & 0.96 & $0.59-1.59$ & \\
\hline & 3 & 24 & 20.9 & 91 & 79.1 & 0.71 & $0.35-1.46$ & \\
\hline & $>=4$ & 12 & 10.1 & 107 & 89.9 & 0.35 & $0.19-0.65$ & \\
\hline Hospitalization & & 60 & 56.6 & 46 & 43.4 & $5.11 * * *$ & $3.57-7.30$ & $<0.001$ \\
\hline Oxygene Therapy & & 97 & 41.5 & 137 & 58.5 & $5.69 * * *$ & $3.17-10.22$ & $<0.001$ \\
\hline Palliative Care & & 33 & 86.8 & 5 & 13.2 & $8.11 * * *$ & $3.77-17.45$ & $<0.001$ \\
\hline $\begin{array}{l}\text { Failure-to-thrive } \\
\text { Syndrome }\end{array}$ & & 74 & 61.2 & 47 & 38.8 & $9.45 * * *$ & $3.09-28.89$ & $<0.001$ \\
\hline \multirow{5}{*}{$\begin{array}{l}\text { Number of } \\
\text { Comorbidities }\end{array}$} & 0 & 43 & 19 & 183 & 81 & Ref & & \multirow{5}{*}{0.187} \\
\hline & 1 & 30 & 20.5 & 116 & 79.5 & 1.05 & $0.65-1.69$ & \\
\hline & 2 & 35 & 26.3 & 98 & 73.7 & 1.25 & $0.81-1.93$ & \\
\hline & 3 & 16 & 27.6 & 42 & 72.4 & 1.42 & $0.85-2.37$ & \\
\hline & $>=4$ & 7 & 31.8 & 15 & 68.2 & $1.85 * *$ & $1.05-3.25$ & \\
\hline Cancer & & 9 & 30 & 21 & 70 & 1.36 & $0.87-2.12$ & 0.294 \\
\hline Obesity & & 4 & 26.7 & 11 & 73.3 & 0.87 & $0.51-1.49$ & 0.887 \\
\hline Cardiovasc. Disease & & 32 & 28.6 & 80 & 71.4 & 1.30 & $0.84-2.00$ & 0.257 \\
\hline High Blood Pressure & & 50 & 24.4 & 155 & 75.6 & 0.89 & $0.65-1.24$ & 0.927 \\
\hline Dementia & & 41 & 24.1 & 129 & 75.9 & 1.00 & $0.74-1.35$ & 0.522 \\
\hline Denutrition & & 9 & 39.1 & 14 & 60.9 & $1.97^{*}$ & $0.91-4.23$ & 0.098 \\
\hline
\end{tabular}


medRxiv preprint doi: https://doi.org/10.1101/2021.12.12.21267681; this version posted December 14, 2021. The copyright holder for this preprint (which was not certified by peer review) is the author/funder, who has granted medRxiv a license to display the preprint in perpetuity.

It is made available under a CC-BY-NC-ND 4.0 International license .

\begin{tabular}{|c|c|c|c|c|c|c|c|c|}
\hline Diabetes & & 15 & 31.9 & 32 & 68.1 & 1.23 & $0.73-2.07$ & 0.217 \\
\hline Respiratory Dis. & & 5 & 20.8 & 19 & 79.2 & 1.04 & $0.43-2.51$ & 0.753 \\
\hline Other comorbidity & & 4 & 20 & 16 & 80 & 1.19 & $0.29-4.83$ & 0.875 \\
\hline \multicolumn{9}{|c|}{ Facility-Level Data } \\
\hline \multirow{3}{*}{ Facility Type } & Private & 21 & 18.6 & 92 & 81.4 & Ref & & \multirow{3}{*}{0.287} \\
\hline & Public & 95 & 24.9 & 287 & 75.1 & 1.07 & $0.62-1.85$ & \\
\hline & \begin{tabular}{|c|} 
Public NH \\
within Hospital \\
\end{tabular} & 15 & 16.7 & 75 & 83.3 & 0.73 & $0.42-1.29$ & \\
\hline & & & & & & & & \\
\hline \multirow{3}{*}{ AWAS (cat.) } & High $(>=800)$ & 73 & 29.1 & 178 & 70.9 & $1.54 * *$ & $1.05-2.28$ & \multirow{3}{*}{$<0.001$} \\
\hline & $\begin{array}{l}\text { Medium (750- } \\
800)\end{array}$ & 13 & 12 & 95 & 88 & 0.56 & $0.23-1.39$ & \\
\hline & Low $(<750)$ & 45 & 19.9 & 181 & 80.1 & Ref & & \\
\hline & & & & & & & & \\
\hline \multirow{3}{*}{ Time to FFP2 use (cat) } & $\begin{array}{l}\text { Immediate } \\
(<=1 \text { day })\end{array}$ & 27 & 22.9 & 91 & 77.1 & Ref & & \multirow{3}{*}{0.525} \\
\hline & \begin{tabular}{|l|} 
Late (1-7 days) \\
\end{tabular} & 32 & 18.9 & 137 & 81.1 & 0.90 & $0.53-1.53$ & \\
\hline & $\begin{array}{c}\begin{array}{c}\text { Very Late }(>=7 \\
\text { days) }\end{array} \\
\end{array}$ & 72 & 24.2 & 226 & 75.8 & 1.03 & $0.52-2.06$ & \\
\hline & & & & & & & & \\
\hline \multirow{3}{*}{$\begin{array}{l}\text { Staff to Resident Ratio } \\
\text { (cat) }\end{array}$} & Good $(>0.9)$ & 67 & 27.8 & 174 & 72.2 & $1.56^{* *}$ & $1.02-2.38$ & \multirow{3}{*}{0.018} \\
\hline & $\begin{array}{l}\text { Medium (0.8- } \\
0.9 \text { ) }\end{array}$ & 34 & 17.9 & 156 & 82.1 & 0.95 & $0.59-1.55$ & \\
\hline & Low $(<0.8)$ & 30 & 19.5 & 124 & 80.5 & Ref & & \\
\hline & & & & & & & & \\
\hline \multirow{3}{*}{$\begin{array}{l}\text { Presence of a } \\
\text { Physician (cat) }\end{array}$} & None/Absent & 39 & 35.8 & 70 & 64.2 & Ref & & \multirow{3}{*}{$<0.001$} \\
\hline & Half-Time & 61 & 18.6 & 267 & 81.4 & $0.50 * * *$ & $0.31-0.80$ & \\
\hline & Full Time & 31 & 20.9 & 117 & 79.1 & $0.43 * * *$ & $0.24-0.75$ & \\
\hline & & & & & & & & \\
\hline \multirow{2}{*}{ NH Size } & $>=70$ residents & 81 & 25.6 & 235 & 74.4 & 1.43 & $0.83-2.44$ & \multirow{2}{*}{0.036} \\
\hline & $<70$ & 50 & 18.6 & 219 & 81.4 & Ref & & \\
\hline \multirow{3}{*}{$\begin{array}{l}\text { Staff Sick Leave } \\
\text { Proportion (cat) }\end{array}$} & & & & & & & & \\
\hline & High (>50\%) & 61 & 27.5 & 161 & 72.5 & Ref & & \multirow{2}{*}{0.030} \\
\hline & Low $(<=50 \%)$ & 47 & 20.7 & 180 & 79.3 & $0.62 * *$ & $0.41-0.95$ & \\
\hline \multirow{3}{*}{ Staff Attack Rate (cat) } & High (>50\%) & 75 & 27,5 & 198 & 72,5 & $2.23 * *$ & $1.13-4.39$ & \multirow{3}{*}{0.025} \\
\hline & $\begin{array}{l}\text { Medium (25- } \\
50 \%)\end{array}$ & 46 & 19,7 & 188 & 80,3 & 1.56 & $0.77-3.14$ & \\
\hline & Low $(<25 \%)$ & 10 & 12,8 & 68 & 87,2 & Ref & & \\
\hline \multirow{4}{*}{$\begin{array}{l}\text { Time to MSF } \\
\text { Intervention (cat) }\end{array}$} & Long (>20 days) & 45 & 24.9 & 136 & 75.1 & Ref & & \multirow{4}{*}{0.234} \\
\hline & $\begin{array}{c}\text { Medium (10 to } \\
20 \mathrm{~d})\end{array}$ & 73 & 22.4 & 253 & 77.6 & 0.78 & $0.47-1.28$ & \\
\hline & Short (<10d) & 13 & 16.7 & 65 & 83.3 & $0.57^{* *}$ & $0.37-0.89$ & \\
\hline & $<14$ days & 26 & 14.6 & 152 & 85.4 & Ref & & \\
\hline COVID outbreak & Yes & 24 & 19.4 & 100 & 80.6 & 0.76 & $0.30-1.93$ & 0.336 \\
\hline
\end{tabular}


medRxiv preprint doi: https://doi.org/10.1101/2021.12.12.21267681; this version posted December 14, 2021. The copyright holder for this preprint (which was not certified by peer review) is the author/funder, who has granted medRxiv a license to display the preprint in perpetuity.

It is made available under a CC-BY-NC-ND 4.0 International license .

\begin{tabular}{|l|l|l|l|l|l|l|}
\hline during the first wave & & & & & & \\
\hline$* p<0.1^{* *} p<0.05^{* * *} p<0.01$
\end{tabular}


medRxiv preprint doi: https://doi.org/10.1101/2021.12.12.21267681; this version posted December 14, 2021. The copyright holder for this preprint (which was not certified by peer review) is the author/funder, who has granted medRxiv a license to display the preprint in perpetuity.

It is made available under a CC-BY-NC-ND 4.0 International license .

Table 2. Multivariate Cox Hazard adjusted analysis of mortality associated factors in French nursing facilities, Provence and Occitania provinces, 2021 (Information Criteria: AIC $^{*}=1171 ; \mathrm{BIC}=1226$ )

\begin{tabular}{|c|c|c|c|c|}
\hline \multicolumn{2}{|l|}{ VARIABLES } & \multirow{2}{*}{ 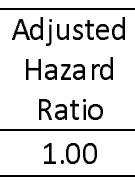 } & \multirow{2}{*}{$\begin{array}{c}\mathrm{Cl} 95 \\
0.98-1.03 \\
\end{array}$} & \multirow{2}{*}{$\begin{array}{c}\text {-value } \\
0.876 \\
\end{array}$} \\
\hline Age & Continuous & & & \\
\hline \multirow{3}{*}{ Autonomy Score } & 2 vs 0 & 0.66 & $0.35-1.27$ & 0.216 \\
\hline & 3 vs 0 & 0.38 & $0.16-0.89$ & 0.026 \\
\hline & $\geq 4$ vs 0 & 0.22 & $0.07-0.66$ & 0.007 \\
\hline Gender & $M$ vs $F$ & 1.78 & $1.18-2.70$ & 0.006 \\
\hline \multirow{4}{*}{ Comorbidities } & 1 vs 0 & 1.92 & $1.04-3.57$ & 0.038 \\
\hline & 2 vs 0 & 1.76 & $0.93-3.32$ & 0.081 \\
\hline & 3 vs 0 & 2.08 & $0.98-4.42$ & 0.056 \\
\hline & $>=4$ vs 0 & 2.51 & $0.96-6.59$ & 0.061 \\
\hline $\begin{array}{l}\text { Failure-to-thrive } \\
\text { Syndrome }\end{array}$ & $\mathrm{Y} \vee N$ & 4.04 & $1.93-8.48$ & 0.000 \\
\hline \multirow{2}{*}{ Presence of a physician } & Half Time vs None/Absent & 0.30 & $0.18-0.51$ & 0.000 \\
\hline & Full Time vs None/Absent & 0.20 & $0.08-0.53$ & 0.001 \\
\hline $\begin{array}{l}\text { Time to FFP2 use (in } \\
\text { days) }\end{array}$ & continuous & 1.05 & $1.02-1.07$ & 0.000 \\
\hline AWAS & continuous & 0.99 & $0.99-1.00$ & 0.020 \\
\hline Staff Attack Rate (\%) & continuous & 2.71 & $0.59-12.42$ & 0.198 \\
\hline \multirow[t]{3}{*}{ Interaction Terms } & $\mathrm{AES}=2 \# \mathrm{FTTS}=1$ & 2.26 & $0.90-5.67$ & 0.083 \\
\hline & AES $=3 \# F T T S=1$ & 3.10\# & $1.00-9.58$ & 0.050 \\
\hline & $\mathrm{AES}=4 \# \mathrm{FTTS}=1$ & 4.79\# & $1.16-19.87$ & 0.031 \\
\hline
\end{tabular}

\# interaction term significant $>$ FTTS effect amplified at each level of AES effect. ${ }^{*}$ Akaike Information Criteria 
medRxiv preprint doi: https://doi.org/10.1101/2021.12.12.21267681; this version posted December 14, 2021. The copyright holder for this preprint (which was not certified by peer review) is the author/funder, who has granted medRxiv a license to display the preprint in perpetuity.

It is made available under a CC-BY-NC-ND 4.0 International license . 
Table 3. Representative quotes for the 3 themes

\begin{tabular}{|c|c|c|c|}
\hline Subthemes & $\begin{array}{l}\text { Quote } \\
\text { number }\end{array}$ & Quotes $^{(1)}$ & $\begin{array}{l}\text { Interviewee } \\
\text { number, Function }\end{array}$ \\
\hline \multicolumn{4}{|c|}{ THEME 1. The Structural and Chronic Neglect of Nursing Homes } \\
\hline \multirow{4}{*}{$\begin{array}{l}\text { Long-Standing } \\
\text { Medical Isolation }\end{array}$} & 1 & $\begin{array}{l}\text { The problem is that we no longer have enough physicians in our areas: the older ones are retiring without } \\
\text { being replaced and those who are still there, they're overloaded with work. }\end{array}$ & 1, Director \\
\hline & 2 & $\begin{array}{l}\text { In March 2020, businesses closed, shops closed, hospitals deprogrammed. (...) However, in the NHs, our } \\
\text { activity stayed the same, we remained full, even with a much higher nervous intensity than usual. }\end{array}$ & 49, Director \\
\hline & 3 & $\begin{array}{l}\text { What was tough was that the Nursing Home turned to a medical service. And before that it wasn't a } \\
\text { medical service at all, it was more of a living space. }\end{array}$ & $\begin{array}{l}\text { 10, Coordinating } \\
\text { Physician }\end{array}$ \\
\hline & 4 & $\begin{array}{l}\text { The nursing home was almost like a hospital ward at one point. Blood tests, all the time, sometimes } 12 \text { a } \\
\text { day. There was more supervision, more care. It was weird because we didn't have the staff to do all that. }\end{array}$ & 23, Nurse \\
\hline \multirow{4}{*}{$\begin{array}{l}\text { Working in } \\
\text { Precarious and } \\
\text { Understaffed } \\
\text { Conditions }\end{array}$} & 5 & $\begin{array}{l}\text { Right now, we have } 1 \text { nurse for } 50 \text { [residents]. So it's not enough! (...) I am convinced that the key issue } \\
\text { for nursing homes is strict staffing ratios. }\end{array}$ & 49, Director \\
\hline & 6 & $\begin{array}{l}\text { My fellow caregivers are telling me, outside of the COVID crisis: "When I go home, I'm not happy with } \\
\text { what I did because I could have done more, but I can't afford to do more, I don't have enough time". I } \\
\text { think that's pretty pathetic. }\end{array}$ & 20 Psychologist \\
\hline & 7 & $\begin{array}{l}\text { Working in a Nursing Home, I did it, but it's not by choice. It's too hard, it's not a question of vocation, but } \\
\text { that the work is too hard. They ask you to do } 15 \text { toilets...Connections with people are rich, you learn a lot. } \\
\text { But the working conditions are hard. When they ask you to help } 13 \text { people to bathe before noon, you } \\
\text { don't work well. I see people who were there for } 30 \text { years and who say "we have no choice". Nursing } \\
\text { homes are hard. }\end{array}$ & 21, Assistant Nurse \\
\hline & 8 & You see, the nurses: when I first came in, there were two of them, each taking a round. But now...They & 3, Resident, Mrs. E. \\
\hline
\end{tabular}




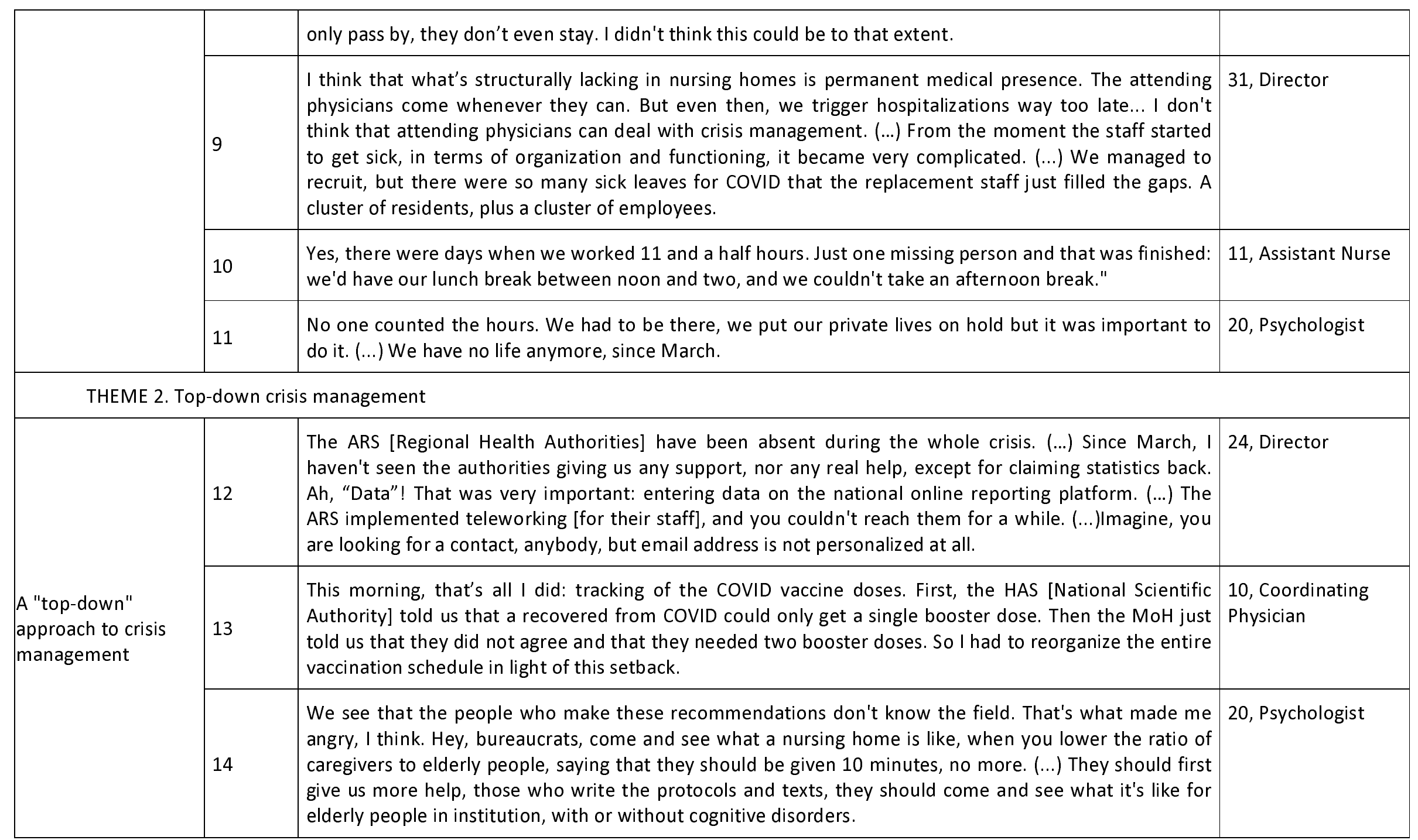




\begin{tabular}{|c|c|c|c|}
\hline \multirow{4}{*}{$\begin{array}{l}\text { Inconsistent and } \\
\text { guilt-laden } \\
\text { recommendations }\end{array}$} & 15 & $\begin{array}{l}\text { We are in an environment where we touch each other all the time. You touch them to change them, to } \\
\text { handle them, to feed them. You spend your time touching! And from one day to the next, you are told: } \\
\text { "don't touch, you'll spread the virus". (...) See, they [the residents] were in jail. They were in a cell. Really, } \\
\text { when the rooms were closed, the nursing homes was empty. And that must have disturbed the residents } \\
\text { but also the caregivers, who were used to touching. }\end{array}$ & 24, Director \\
\hline & 16 & $\begin{array}{l}\text { Look, some people had to be uprooted from their rooms. Our residents have cognitive disorders; they are } \\
\text { very attached to their rooms. They have spatial-temporal and autobiographical markers inside. And } \\
\text { suddenly, we had to remove everything, to put them in a different room, without their belongings, } \\
\text { because they were potentially contaminated. This was difficult, I opposed it. I said we couldn't do that. } \\
\text { Okay, there is COVID, but we are a Nursing Home! (...) Here, I have seen colleagues, assistant nurses, } \\
\text { crying while tying people up, telling them: "I'm sorry I have to tie you up, because it is to protect you, in } \\
\text { fact". (...) It was really a war, they told me: "but we have to do this". Just like me, I said to myself: "but at } \\
\text { some point, we haven't signed up for this", we are Nursing Home! }\end{array}$ & 20, Psychologist \\
\hline & 17 & $\begin{array}{l}\text { For example, I remember in the service I was in, two people had a very hard time with the confinement, } \\
\text { who had to be restrained, and it was really not easy for us and for the residents. }\end{array}$ & 16, Assistant Nurse \\
\hline & 18 & $\begin{array}{l}\text { At one point, during the first lockdown, we had to stay in our room. We had dinner in the rooms. Then it } \\
\text { was hard. It lasted for a long time. We were not allowed to go out anymore. Even those who were not } \\
\text { sick! The time to get everything sorted. It was hard, staying in the room for a whole day, without going } \\
\text { out...Anyone would become nuts! }\end{array}$ & 57, Resident, Mrs C. \\
\hline \multirow{3}{*}{$\begin{array}{l}\text { Weakly armed } \\
\text { mechanisms and } \\
\text { actors for crisis } \\
\text { situations }\end{array}$} & 19 & $\begin{array}{l}\text { We experienced successive stresses. The masks, which we could not find! We had to beg, practically. (...) I } \\
\text { remember going to the pharmacies to find overcoats on Saturdays. (...) It wasn't a lack of foresight, it was } \\
\text { that we couldn't find them, people were rushing to stock them, there were no supplies. }\end{array}$ & 24, Director \\
\hline & 20 & $\begin{array}{l}\text { I had already warned the ARS about the shortage of caregivers. I asked them to activate the health } \\
\text { reserve, and I never got any help in managing the situation. We feel very lonely in dealing with given } \\
\text { situations. (...) No matter how many times I called the ARS, they sent me to platforms that don't work. } \\
\text { The national recruitment platform. And we've lost a lot of time. (...) Staff turnover was also an infection } \\
\text { risk. Many of the people we took on as replacements got sick later on. }\end{array}$ & 31, Director \\
\hline & 21 & You can feel that the fatigue of the first lockdown is still here [for the staff]. Because it is still an overload. & 57, Resident, Mrs C. \\
\hline
\end{tabular}




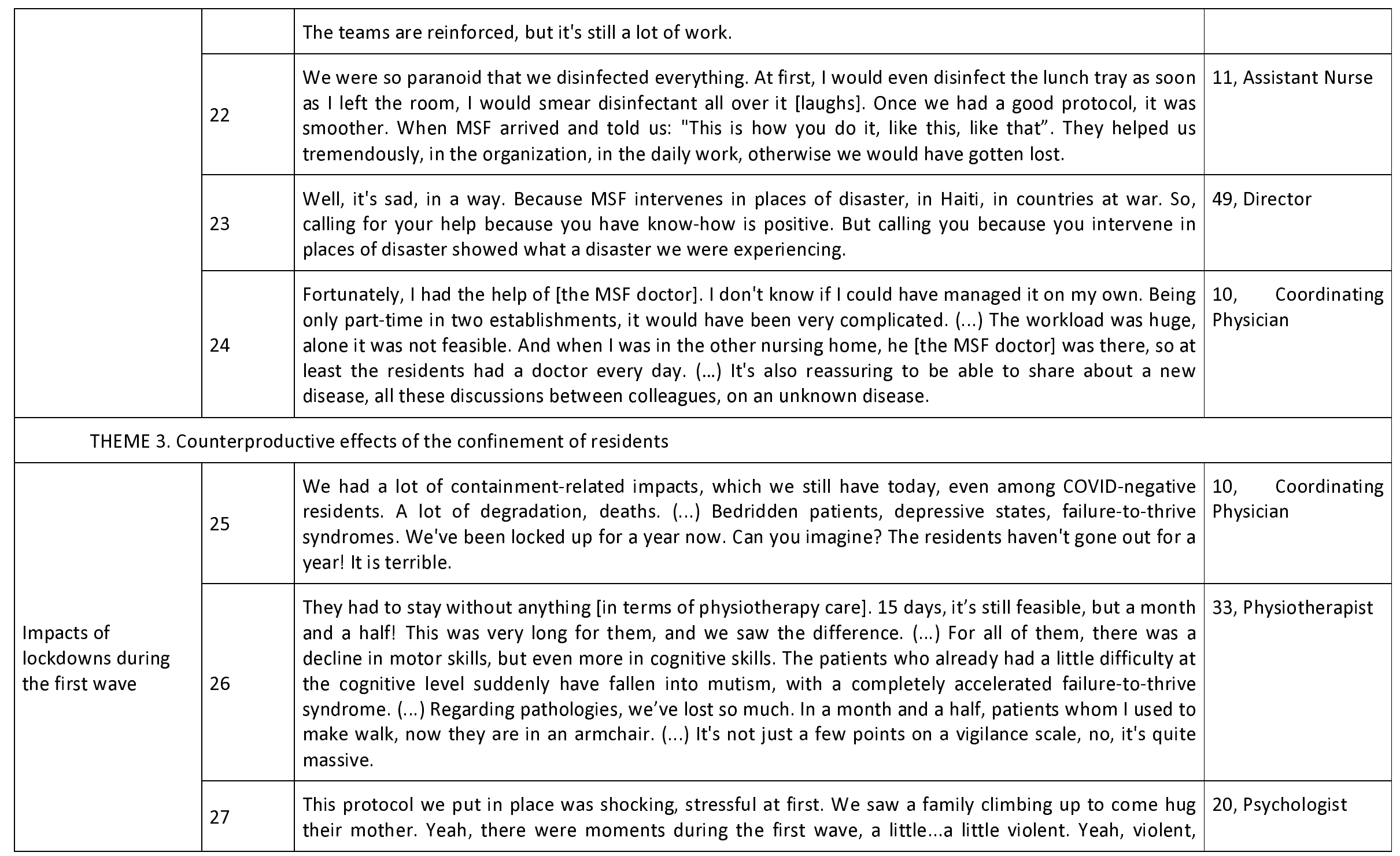




\begin{tabular}{|c|c|c|c|}
\hline & & outright. & \\
\hline \multirow{7}{*}{$\begin{array}{l}\text { The silenced } \\
\text { opinions of nursing } \\
\text { home residents }\end{array}$} & 28 & $\begin{array}{l}\text { Finally, we did not ask the residents their opinion. We confined as recommended. We didn't have much } \\
\text { choice. (...) We have residents here who never had any symptoms, so it's a bit of a double whammy: I'm } \\
\text { sick, I'm fine, but then I'm stuck in my room. }\end{array}$ & 1, Director \\
\hline & 29 & $\begin{array}{l}\text { What bothered me about the lockdown was that the resident's opinion was never asked. (...) The only } \\
\text { things I was hearing of was disaster scenarios, with many deaths, many sick staff. A lot of confinements in } \\
\text { rooms, and in the end the results were not necessarily conclusive. }\end{array}$ & 49, Director \\
\hline & 30 & $\begin{array}{l}\text { Finally, I'm glad I arrived here before, because I was in a fragile period before, it would have been even } \\
\text { more difficult. So I'm glad I came. Right now I'm in the right place at the right time. }\end{array}$ & 57, Resident, Mrs C. \\
\hline & 31 & $\begin{array}{l}\text { When this microbe is gone, as soon as we can go out, my daughter will come and get me, because her } \\
\text { house is in [the same village]. (...) I would like us to be able to go out again at some point, but we have to } \\
\text { bring the staff back. And with the disease.... This microbe is always there, we can't live normally. }\end{array}$ & 3, Resident, Mrs E. \\
\hline & 32 & $\begin{array}{l}\text { The room, we stayed in there for a few days straight, you see! Can you tell? From breakfast to supper, in a } \\
\text { room! It is not in my nature. (...) It was not fun. Especially since these rooms are small; they can't be } \\
40 \mathrm{~m} 2 \text {. }\end{array}$ & 6, Resident, Mrs. Q \\
\hline & 33 & $\begin{array}{l}\text { These activities we used to have, these games, twice a week. It was a nice break during a week. I miss } \\
\text { that. Now, every day of the week looks the same. }\end{array}$ & 57, Resident, Mrs C. \\
\hline & 34 & $\begin{array}{l}\text { (Mme A.) When this illness happened, we were no longer allowed to do anything. We no longer have } \\
\text { outings, we have nothing, nothing, nothing. (...) The COVID period, there, it hurts because you don't see } \\
\text { anybody. You only see those who are inside [the nursing homes]. } \\
\text { (Mme O.) We are isolated, left to ourselves. (...) Now I can only see my daughter behind a Plexiglas. So the } \\
\text { mask, the glass... We don't understand a lot. } \\
\text { (Mme A.) We have to speak a bit louder than normal. And we can't touch each other, we only kiss from } \\
\text { far away. This is annoying, not being able to hug them! } \\
\text { (Mme O.) We can't kiss hello or goodbye, nothing! We are separated by a Plexiglas. } \\
\text { (Investigator) And you would prefer that people could come in the nursing homes? } \\
\text { (Mme A.) Of course! We should see them a little more! }\end{array}$ & $\begin{array}{l}\text { 36, Resident, Mrs A. } \\
\text { 37, Resident, Mrs O. }\end{array}$ \\
\hline
\end{tabular}




\begin{tabular}{|c|c|c|c|}
\hline & 35 & $\begin{array}{l}\text { If I could go out on Sundays, I would be the happiest. (...) If we could go out, we would bear it better. (...) } \\
\text { Things should go back to normal again. Just because there's a virus out there doesn't mean that } \\
\text { everything should stop! }\end{array}$ & 6, Resident, Mrs. Q. \\
\hline \multirow{5}{*}{$\begin{array}{l}\text { The courage to lift } \\
\text { the containment } \\
\text { measures }\end{array}$} & 36 & $\begin{array}{l}\text { We followed the recommendations, to the letter. After that, there is the reality of the field. (...) If I } \\
\text { applied the recommendations, I would put everyone in isolation, because there is still active virus } \\
\text { circulation, and visits would not have resumed here. It is not acceptable to ban visits. But it is the } \\
\text { director's responsibility. }\end{array}$ & 31, Director \\
\hline & 37 & $\begin{array}{l}\text { We decided to open the visits for families again, including for those suffering from failure-to-thrive } \\
\text { syndrome, and not only for the "end of life" ones. Because our job is to be human. So at some point, } \\
\text { people need to see their parents, their parents need to see their children. We have to be able to do all } \\
\text { that, while respecting public health measures and so on. }\end{array}$ & 1, Director \\
\hline & 38 & $\begin{array}{l}\text { With this decision, to not confine them in their room, this year we really did what they wanted. And I } \\
\text { think we'd never done it, actually, exactly what they wanted. (...) When you know that COVID is coming } \\
\text { in, you accept that there will be deaths. The question is the conditions around the death. }\end{array}$ & 49, Director \\
\hline & 39 & $\begin{array}{l}\text { We're not here to generate failure-to-thrive syndromes or severe depressive states either. So I told the } \\
\text { girls: "you wash his hands well when he comes out of the room, but we set him free!". Because that was } \\
\text { really the point: the impression of locking people even more. They are } 91 \text { years old, } 92 \text { years old, so that's } \\
\text { enough! }\end{array}$ & $\begin{array}{l}\text { 10, Coordinating } \\
\text { Physician }\end{array}$ \\
\hline & 40 & $\begin{array}{l}\text { When we reopened the dining room, we saw residents expressing a desire to eat with this or that other } \\
\text { resident. Relationships, loving couples forming. All of that, it didn't exist anymore, they were isolated in } \\
\text { their rooms, and there was no relationship between them anymore. }\end{array}$ & 1, Director \\
\hline
\end{tabular}

